\title{
Analysing Crisis Communication Strategies of Airline Companies in United States: \\ A Case Study of Southwest Airline 2016 Power Outage Crisis
}

\author{
Mavis Boamah \\ Correspondence: Mavis Boamah, Faculty of Arts and Education, Deakin University, Melbourne, Australia. \\ Received: October 12, 2018 \\ Accepted: March 1, $2018 \quad$ Online Published: April 1, 2019 \\ doi:10.11114/smc.v7i1.4190 \\ URL: https://doi.org/10.11114/smc.v7i1.4190
}

\begin{abstract}
Companies are vulnerable to crisis. Crisis are a threat to organisational reputation and can harm stakeholders physically, emotionally and financially. One key technique to ensuring the happenings of crisis are minimised is communication. Communication plays the role of ensuring the reputation and credibility of a company is safeguarded. The modern way of communication and information sharing has been a vital part for businesses to survive. Emergency situations in airlines are inevitable and as such the company's ability to communicate through its online sites is critical to averting and combating future crisis. As one of the famous airline companies in America, Southwest airline is present on all social media platforms to connect with its stakeholders. This was evident in its crisis management strategy during the 15-hour power outage in July 2016 which led to the cancellation of over 2.000 flights and delayed 250.000 travellers. The innovative communication strategies and tactics employed by southwest communications team reduced the level of damage the crisis could have caused. This paper analyses the airline's communication strategies and tactics in the crisis and its impact on victims of the crisis.
\end{abstract}

Keywords: southwest airline, crisis, airline crisis, southwest, airline reputation, airline management, crisis management

\section{Company Background}

\subsection{Southwest Airline}

Formed in 1971 by Rollin King and Herb Kelleher, Southwest airline began its operation with three Boeing 737 aircraft that served Houston, San Antonio and Dallas cities in Texas (Carter, Rogers \& Simkins, 2004). After its establishment till date, Southwest airline company is mainly known for its less cost fares in the United States. The airline charges less fare for its customers because it has been its core strategy since its formation (Lauer 2010; Southwest n.d.). This strategy may form part of the Airline's success stories. 
Table 1. The table below shows the financial and market value of Southwest Airline among its competitors

(Southwest Stock Report 2014)

\begin{tabular}{|c|c|c|c|c|c|c|c|c|c|}
\hline \multicolumn{10}{|l|}{ EV Multiples \& Credit Ratios } \\
\hline Name & Ticker & $\begin{array}{r}\text { Last Period } \\
\text { End Date } \\
\end{array}$ & $\begin{array}{r}\text { EV/Sales } \\
\text { TाM }\end{array}$ & $\begin{array}{r}\text { EVIEBITDA } \\
\text { TTM } \\
\end{array}$ & $\begin{array}{r}\text { EVIEBIT } \\
\text { TTM } \\
\end{array}$ & $\begin{array}{r}\text { Total Debt } \\
\text { EV } \\
\end{array}$ & $\begin{array}{r}\text { Net Debt } \\
\text { EV }\end{array}$ & $\begin{array}{r}\text { Total Debt/ } \\
\text { Equity }\end{array}$ & $\begin{array}{r}\text { Net Debtt } \\
\text { Equity }\end{array}$ \\
\hline SOUTHWEST AIRLINES CO. & LUV-US & 03/31/2016 & 1.44 & 6.19 & 7.98 & 0.11 & NEG & 0.44 & $(0.04)$ \\
\hline DELTA AIR LINES, INC. & DAL-N & $03 / 31 / 2016$ & 0.91 & 3.81 & 4.71 & 0.23 & 0.09 & 0.75 & 0.30 \\
\hline JETBLUE AIRWAYS CORPORATION & JBLU-O & $12 / 31 / 2015$ & 1.17 & 4.81 & 6.17 & 0.25 & 0.13 & 0.57 & 0.30 \\
\hline UNITED CONTINENTAL HOLDINGS, INC. & UAL-N & $03 / 31 / 2016$ & 0.65 & 3.62 & 5.03 & 0.48 & 0.32 & 1.48 & 0.97 \\
\hline AMERICAN AIRLINES GROUP INC. & AAL 0 & $03 / 31 / 2016$ & 0.87 & 4.84 & 6.23 & 0.61 & 0.40 & 4.62 & 3.00 \\
\hline SPIRIT AIRLINES, INC. & SAVE-O & $12 / 31 / 2015$ & 1.54 & 5.64 & 6.45 & 0.20 & NEG & 0.53 & (0.13) \\
\hline ALASKA AIR GROUP, INC. & ALK-N & $12 / 31 / 2015$ & 1.54 & 5.24 & 6.51 & 0.08 & NEG & 0.28 & (0.27) \\
\hline ALLEGIANT TRAVEL COMPANY & ALGT-O & $12 / 31 / 2015$ & 2.50 & 6.71 & 8.47 & 0.20 & 0.09 & 1.83 & 0.85 \\
\hline VIRGIN AMERICA INC. & VA-O & $12 / 31 / 2015$ & 1.24 & 9.71 & 10.73 & 0.16 & NEG & 0.38 & (0.23) \\
\hline Copa Holdings & CPA-N & $12 / 31 / 2015$ & 1.58 & 9.12 & 13.94 & 0.36 & 0.17 & 0.65 & 0.31 \\
\hline HAWAIIAN HOLDINGS, INC. & HA-O & $03 / 31 / 2016$ & 1.02 & 4.80 & 6.15 & 0.29 & 0.00 & 1.40 & 0.02 \\
\hline Mean & & & 1.32 & 5.86 & 7.49 & 0.27 & 0.09 & 1.18 & 0.46 \\
\hline Median & & & 1.24 & 5.24 & 6.45 & 0.23 & 0.09 & 0.65 & 0.30 \\
\hline High & & & 2.50 & 9.71 & 13.94 & 0.61 & 0.40 & 4.62 & 3.00 \\
\hline Low & & & 0.65 & 3.62 & 4.71 & 0.08 & 0.00 & 0.28 & $(0.27)$ \\
\hline
\end{tabular}

\begin{tabular}{|c|c|c|c|c|c|c|c|c|c|c|}
\hline \multicolumn{11}{|l|}{ Key Flnanclals \& Effectiveness } \\
\hline Name & $\begin{array}{r}\text { Sales } \\
\text { TM }\end{array}$ & $\begin{array}{r}\text { EBITDA } \\
\text { TTM }\end{array}$ & $\begin{array}{r}\text { EBITDA } \\
\text { Year/Year }\end{array}$ & $\begin{array}{c}\mathrm{EBIT} \\
\mathrm{TMM} \\
\end{array}$ & $\begin{array}{r}\text { Net Income } \\
\pi \mathrm{M}\end{array}$ & $\begin{array}{r}\text { Net Margin } \\
\text { TाM }\end{array}$ & $\begin{array}{l}\text { EPS } \\
\text { TTM }\end{array}$ & $\begin{array}{r}\text { EPS } \\
\text { learYYear }\end{array}$ & $\begin{array}{l}\text { ROA } \\
\text { TIM }\end{array}$ & $\begin{array}{l}\text { ROE } \\
\text { TTM }\end{array}$ \\
\hline SOUTHWEST AIRLINES CO. & $20,232.00$ & $4,721.00$ & 1.40 & $3,660.00$ & $2,243.00$ & $11.09 \%$ & 3.39 & 1.62 & $10.88 \%$ & $31.16 \%$ \\
\hline DELTA AIR LINES, INC. & $40,567.00$ & $9,713.00$ & 225 & $7,862.00$ & $4,726.00$ & $11.65 \%$ & 5.94 & 4.17 & $10.52 \%$ & $46.57 \%$ \\
\hline JETBLUE AIRWAYS CORPORATION & $6,416.00$ & $1,563.00$ & 1.45 & $1,218.00$ & 677.00 & $10.55 \%$ & 1.98 & 1.69 & $9.22 \%$ & $23.59 \%$ \\
\hline UNITED CONTINENTAL HOLDINGS, INC. & $37,451.00$ & $6,677.00$ & 1.45 & $4,808.00$ & $7,145.00$ & $19.08 \%$ & 19.00 & 291 & $20.09 \%$ & $131.73 \%$ \\
\hline AMERICAN AIRLINES GROUP INC. & $40,598.00$ & $7,332.00$ & 1.21 & $5,694.00$ & $7,378.00$ & $18.17 \%$ & 10.86 & 235 & $17.62 \%$ & $197.43 \%$ \\
\hline SPIRIT AIRLINES, INC. & $2,141.46$ & 585.14 & 1.46 & 511.23 & 317.22 & $14.81 \%$ & 4.38 & 1.41 & $15.99 \%$ & $28.47 \%$ \\
\hline ALASKA AIR GROUP, INC. & $5,598.00$ & $1,640.00$ & 1.26 & $1,320.00$ & 848.00 & $15.15 \%$ & 6.55 & 1.48 & $13.77 \%$ & $37.37 \%$ \\
\hline ALLEGIANT TRAVEL COMPANY & $1,262.19$ & 471.19 & 1.95 & 373.09 & 219.41 & $17.39 \%$ & 12.94 & 2.66 & $18.27 \%$ & $68.26 \%$ \\
\hline VIRGIN AMERICA INC. & $1,529.58$ & 195.88 & 1.77 & 177.24 & 340.54 & $22.26 \%$ & 7.66 & 6.36 & $29.13 \%$ & $53.74 \%$ \\
\hline Copa Holdings & $2,250.06$ & 390.70 & 0.72 & 255.81 & 185.42 & $8.24 \%$ & 4.23 & 0.52 & $5.18 \%$ & $9.10 \%$ \\
\hline HAWAIIAN HOLDINGS, INC. & $2,328.37$ & 493.48 & 1.54 & 384.70 & 208.23 & $8.94 \%$ & 3.54 & 2.26 & $10.12 \%$ & $52.72 \%$ \\
\hline Mean & $14,579.42$ & $3,071.13$ & 1.50 & $2,387.64$ & $2,207.98$ & $14.30 \%$ & 7.32 & 2.49 & $14.62 \%$ & $61.83 \%$ \\
\hline Median & $5,598.00$ & $1,563.00$ & 1.45 & $1,218.00$ & 677.00 & $14.81 \%$ & 5.94 & 226 & $13.77 \%$ & $46.57 \%$ \\
\hline High & $40,598.00$ & $9,713.00$ & 2.25 & $7,862.00$ & $7,378.00$ & $22.26 \%$ & 19.00 & 6.36 & $29.13 \%$ & $197.43 \%$ \\
\hline Low & $1,262.19$ & 195.88 & 0.72 & 177.24 & 185.42 & $8.24 \%$ & 1.98 & 0.52 & $5.18 \%$ & $9.10 \%$ \\
\hline \multicolumn{11}{|l|}{ Market Data \& Price Multiples } \\
\hline Name & Ticker & & Price & $\begin{array}{l}\text { Market Cap: } \\
\text { Consolidated }\end{array}$ & $\begin{array}{r}\text { Enterprise } \\
\text { Value }\end{array}$ & $\begin{array}{l}P / E \\
T M M\end{array}$ & $\begin{array}{r}\text { Price/ } \\
\text { Cash Flow TTM }\end{array}$ & & $\begin{array}{r}\text { Price/ } \\
\text { Book Value } \\
\end{array}$ & $\begin{array}{r}\text { Price/ } \\
\text { BV Tangible } \\
\end{array}$ \\
\hline SOUTHWEST AIRLINES CO. & LUV-US & & 46.18 & $29,492.25$ & $29,218.25$ & 13.63 & 10.46 & & 4.04 & 4.78 \\
\hline DELTA AIR LINES, INC. & DAL-N & & 43.59 & $33,633.22$ & $36,991.22$ & 7.33 & 4.99 & & 3.34 & NEG \\
\hline JETBLUE AIRWAYS CORPORATION & JBLU-O & & 20.33 & $6,547.20$ & $7,514.20$ & 10.29 & 4.84 & & 2.27 & 2.10 \\
\hline UNITED CONTINENTAL HOLDINGS, INC. & UAL-N & & 49.14 & $16,551.48$ & $24,185.48$ & 2.59 & 3.18 & & 2.59 & NEG \\
\hline AMERICAN AIRLINES GROUP INC. & ALLOO & & 36.92 & $21,346.09$ & $35,469.09$ & 3.40 & 3.63 & & 5.10 & NEG \\
\hline SPIRIT AIRLINES, INC. & SAVE-O & & 47.43 & $3,456.54$ & 3.299 .24 & 10.83 & 6.12 & & 2.33 & 2.77 \\
\hline ALASKA AIR GROUP, INC. & ALK-N & & 74.35 & $9,236.01$ & $8,594.01$ & 11.34 & 7.70 & & 4.18 & 3.86 \\
\hline ALLEGIANT TRAVEL COMPANY & ALGT-O & & 170.36 & 2.861 .95 & $3,160.58$ & 13.17 & 8.47 & & 8.06 & 8.18 \\
\hline VIRGIN AMERICA INC. & VA-O & & 55.43 & $2,090.71$ & $1,902.10$ & 7.24 & 12.66 & & 1.99 & 3.25 \\
\hline Copa Holdings & CPA-N & & 67.11 & $2,947.17$ & 3.564.97 & 15.87 & 8.92 & & 1.01 & 1.46 \\
\hline HAWAIIAN HOLDINGS, INC. & HA.O & & 44.01 & $2,358.46$ & $2,367.17$ & 12.42 & 5.35 & & 5.20 & 6.52 \\
\hline Mean & & & - & - & - & 9.83 & 6.94 & & 3.65 & -1.03 \\
\hline Median & & & - & - & - & 10.83 & 6.12 & & 3.34 & 2.77 \\
\hline High & & & 170.36 & 33.633 .22 & $36,991.22$ & 15.87 & 12.66 & & 8.06 & 8.18 \\
\hline Low & & & 20.33 & $2,090.71$ & $1,902.10$ & 2.59 & 3.18 & & 1.01 & 1.46 \\
\hline
\end{tabular}

The success story of Southwest Airline can be demonstrated as it was the first airline to win the coveted Triple Crown for a month - Best on Time Record, Best Baggage Handling and Fewest Customer Complaints ((Carter et al, 2004). The airline has since won five annual Triple Crowns on five consecutive times: 1992, 1993, 1994, 1995 and 1996 (Carter et al, 2004). The airline is also known for its creativity and innovation. Carter et al., (2004) in their study 'Fuel Hedging in the Airline Industry: The case of Southwest Airlines' indicates that Southwest airlines were the first to introduce frequent flyer programme to give credit for the number of trips taken and not the number of miles flown.

Juxtaposing Southwest Airline to others such as Virgin America, American Airlines, Delta, JetBlue and Spirit Airlines as main competitors on the stock market, Southwest airline could stand tall with its strategic pricing policy (Carter et al, 2004). By the year 2000, the small Texas airline with three Boeing 737 aircraft had evolved to be the fourth largest US. carrier based on domestic passengers, operating with 344 Boeing 737 aircraft at the end of 2000 (Carter et al, 2004). Southwest airline has maintained a strong financial reputation over the years making them one of the top successful airlines in the United States (Kelly, CEO, Southwest Airline, 2018). 


\section{Methodology}

The study is a case based to comprehensively understand Southwest Airline and the crisis it confronted. This aims at critically analysing the communication tactics and strategies used by the Airline Company amid their technological failure crises on July 2016.

Information was gathered though several reviews and literature available publicly, including Deakin library database, data found on the company's website, social media site (company and other competitor), crisis articles expounded by different news outlets and records released by Southwest itself. The data timeframe analysed content from 2014, 2015 to study the background of the company and its position in the market prior to the crisis and news articles, reviews were researched majorly from June- November 2016 to study the effect during and after the crisis.

The strength of this method of data collection is that it allowed the use of many articles, media and social media outlets to get to the core of the crisis and how the company addressed it. However, there was limited information or releases that could be acquired directly from company's archives

\section{Results and Discussion}

This section discusses the crisis that bedeviled Southwest Airline Company in June 2016. It gives account of the crisis background, how the crisis was framed by various stakeholders and its corresponding impact on the stakeholders.

\section{Analysis of Crisis - Background}

At about 1p.m on Wednesday July 20, Southwest customers took onto social media with many tweets and posts complaining about inability to check in their flights and use the self-serve kiosks at airports around the country. In the next hour, the airline experienced a technical outage caused by a failed router grounding several thousands of flights and throwing the plans of tens of thousands of people into disarray. The system shutdown which lasted for 15 hours delayed thousands of travelers around the country with over 2.000 flight canceled. The extent of damage and disruptions on the company while it made attempts to repair and restore the system had significant impact on the company's reputation (Dallas News, 2016; CBS News, 2016).

\subsection{Classification of Crisis}

Crisis in organisations damage organisational reputation and such damage is possible to affect how stakeholders such as customers, investors, regulators, shareholders interact with the organisation (Barton, 2001; Dowling, 2002 Cited in Coombs, 2007). Businesses today are more vulnerable to crisis than before and as such Coombs and Holladay (2005) recommends post communication crisis can be used to repair organisation's reputation and prevent reputational damage. The Situational Crisis Communication Theory (SCCT) by Coombs (2007) classifies crisis and provides guidelines on how crisis managers can use response strategies to repair and restore organisation's reputation. According to SCCT, any issue that is sudden, unexpected, technical error and spread within hours like that of Southwest system outage can be classified as accidental cluster.

After crisis has been identified which in this case is accidental cluster, Coombs, (2007) provides strategies that can be used to minimise its adverse effect. Crisis Response Strategies are used to repair the reputation, to reduce negative effect and to prevent negative behavioural intentions (Bradford \& Garrett, 1995 Cited in Coombs, 2007). Crisis responses strategies come in three groups based on the perception and acceptability of a crisis; A. Denial B. Diminish C. Rebuild (Coombs, 2006). Combs (2006) mentions that the right response for accidental cluster is Diminishing and Rebuilding.

Diminishing response happens when an organisation minimises its responsibility for a crisis by denying intent to do harm through justification of the cause of the crisis. This response reduces the impact of crisis on organisations and finds reasons that is not within the organisation's control (Coombs, 2007)

Rebuilding response is used to gain trust from stakeholders and restore reputation. This is done by acknowledging crisis, taking responsibility, offering apology and compensating affected stakeholders (Coombs, 2007).

\subsection{How Southwest Crisis Was Framed}

The theory of framing in communication is where an issue is viewed from a variety of perspective's and constructed as having multiple implications (Chong \& Druckman, 2007). In the southwest airline crisis, three groups of people framed the crisis. The media, stakeholders (regulators and travelers) and the airline company.

\subsection{Media}

Being the watchdog of society, the media never relented on its efforts to bring to light what travelers across United States have been through over Southwest airline's 15 hour power outage. Once the crisis hit the company and its stakeholders (travellers), the media swung into action sensationalising and framing the story, they were constantly tracking the company's progress and updating the public (see image 1). Transportation correspondent Kris Van Cleave reported for 
CBS news stating that, "Southwest put a halt on all its departing flights nationwide due to system glitch" (CBS News, 2016). E.J. Schultz a reporter for the Ad Age was a fellow traveller who was catching a flight from Southwest Chicago terminal shared his experience with the media, he said that, ".... the Southwest officials stopped all traveller who carried an electronic copy of the tickets at the terminal gate and asked them to form a separate line while the

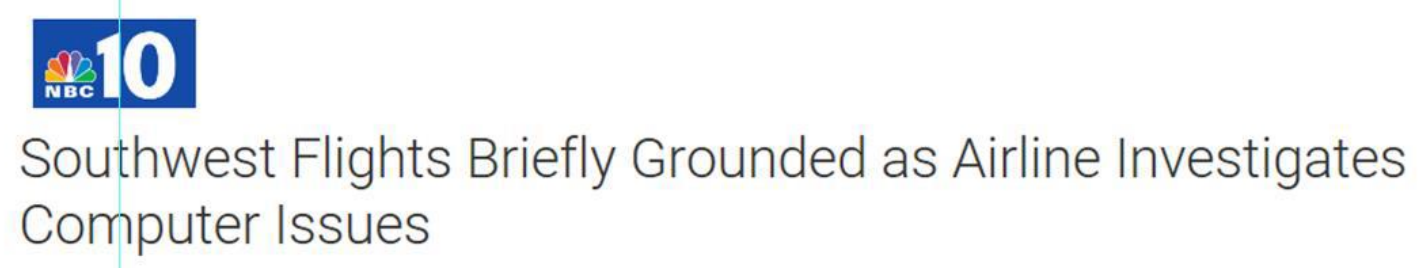

The airline said it would be offering "flexible accommodations for rebooking your travel" once its systems resumed "full functionality"
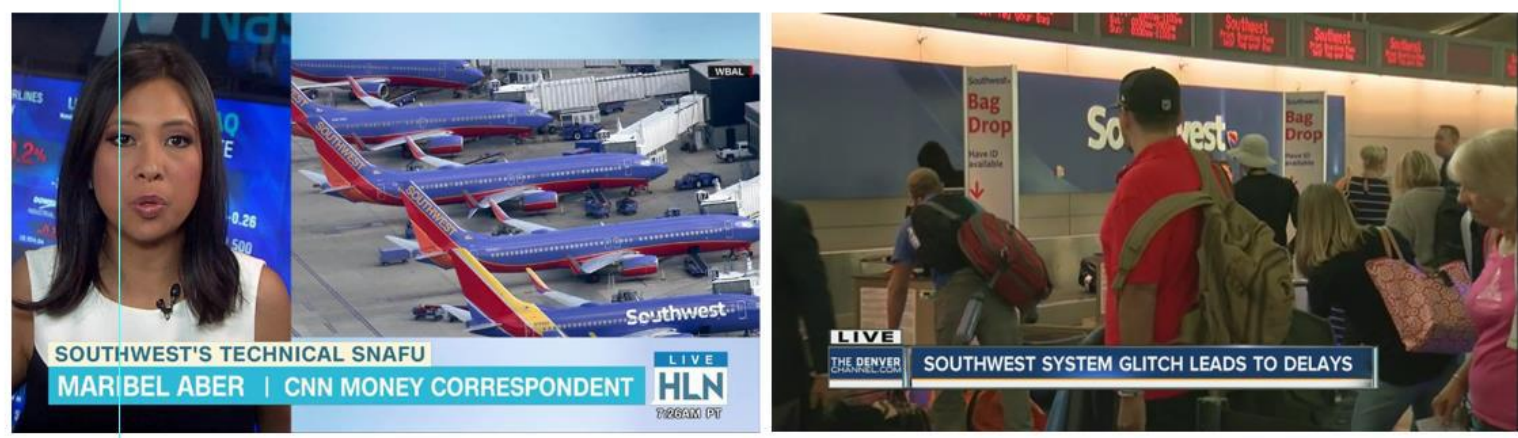

\section{FOX [il \\ Southwest Airlines experiences nationwide outage, flight delays}

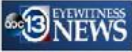

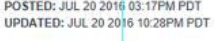
TRAVEI

Southwest Airlines experiencing flight delays after nationwide outage

Image 1. Media channels and newspapers reporting the news (Fox News, 2016; CBS News, 2016; Google Images)

\subsection{Regulators}

NBC News reported the "Federal Regulators are investigating the massive southwest power outage that left millions of people in the dark" (NBC News, 2011). The Federal Energy Regulatory Commission (FERC) has launched its investigation with the North American Electric Reliability Corporation to explore the possible cause of the outage (NBC station KNSD, 2011). FERC spokeswoman, Mary O'Driscoll said in a statement that "If any regulatory violations are found, the commission could issue fines of up to 1 million dollars per day for every violation". The chairman of the commission, John Wellingholf in a written statement copied NBC News cautioned that "the enquiry the spokeswoman said is an effective way for the commission to protect consumers and ensure the reliability of the bulk power system" NBC News, 2011).

\subsection{Travelers}

The travellers framed the crises too, but more on an emotional stand point; they tweeted, posted and shared pictures about their experiences, feelings on social media sites (see picture Social media is known as platform to find and seek potential news lead and this influx of viral feeds caught the attention of several media hubs, thus lifting the company's level of damage and risk management to its highest point. These travelers expressed their dissatisfaction and disappointment through posts and tweets on facebook and twitter. Twitter especially was flooded with tweets from angry travelers calling for refund of their fares and compensation. While some missed their business appointments, others could not make it to job and school interviews. The emotional expressions of the travelers can be seen below (See image 2) 
Matthew Bailey

@Cyborgmatt

@SouthwestAir strung us along for over 8 hours whilst holding our bags hostage. We now have to drive to Starladder w/ all of our TI luggage

9:02 PM - 20 Jul 2016 · San Jose, CA

4 $2722 * 130$

Sam

@BulbaDota

Hey@SouthwestAir your customer service is horrible and you made@teamsecret wait for 8 hours in the airport just to cancel our flight

8:37 PM - 20 Jul 2016

ค $2780 \bullet 304$

Kelli Downard @Kelli_Downard.May 30

I will never \#flyfrontier again. Worst airline ever!. Get me back on

\#SouthwestAirlines!

4 2 络 07
Clement Ivanov

@CLEMENTINATOR

Follow

I am very disappointed in @SouthwestAir because they lied to us, our flight was cancelled but they kept us waiting. We might miss StarLadder

8:37 PM - 20 Jul 2016

ค 2 ? $145 \cdot 580$

6

Follow

Jackson6

@.JacksonKrecioch

@SouthwestAir I hate you so much right now 2:40 PM - 20 Jul 2016

h 2 ใ? $128 \cup 961$

6

6) Hoon

Follow

@S SouthwestAir - how are you going to make this up to customers? tweet doesnt cut it. A refund and credit \#southwest \#southwestairlines

12:55 PM - 20 Jul 2016

ค $2772 * 201$

$\theta$

Image 2. Frustrated tweets on social media by travellers (\#southwest, n.d.)

\subsection{Company - Southwest Airline}

Many experts and media professionals have come out to express their satisfaction over how southwest airline handled its crisis, though the crisis caused a lot of damage and the magnitude was nearly unprecedented in the history of American aviation. Southwest airline company acknowledged and framed the situation as crisis. A social media and content marketing consultant, Jay Baer in his blog post commended southwest communication team on how the crisis was managed to reduce the level of damage. Jay was impressed on how the company acknowledged the crisis, owned it, apologized and provided up to date information to customers and gave them assurance of the incessant efforts by the technical team to restore power.

Not only did the company apologise and updated customers on the crisis, it also assured customers of a refund, flexible accommodation bookings and compensations for the time and inconveniences created due to the technical error.

Table 2. Summary of how the crisis was framed by southwest, media and travelers.

\begin{tabular}{l|l}
\hline Who framed the crisis & How crisis was framed \\
\hline Southwest Airline Company & Recognizing, accepting and apologizing \\
\hline & Assurance of power restoration \\
\hline & Providing refunds to customers \\
\hline Travelers & Compensating customers \\
\hline Media & Assuring customers of better service \\
\hline & $\begin{array}{l}\text { Frustration, dissatisfaction feelings through social } \\
\text { media posts }\end{array}$ \\
\hline & $\begin{array}{l}\text { Taking keen interest in the crisis and sensationalizing } \\
\text { stories for more readership. }\end{array}$ \\
\hline
\end{tabular}




\subsection{Crisis Impact}

Table 3. Lifecycle Model: Hainsworth and Meng (Regester and Larkin, 2008)

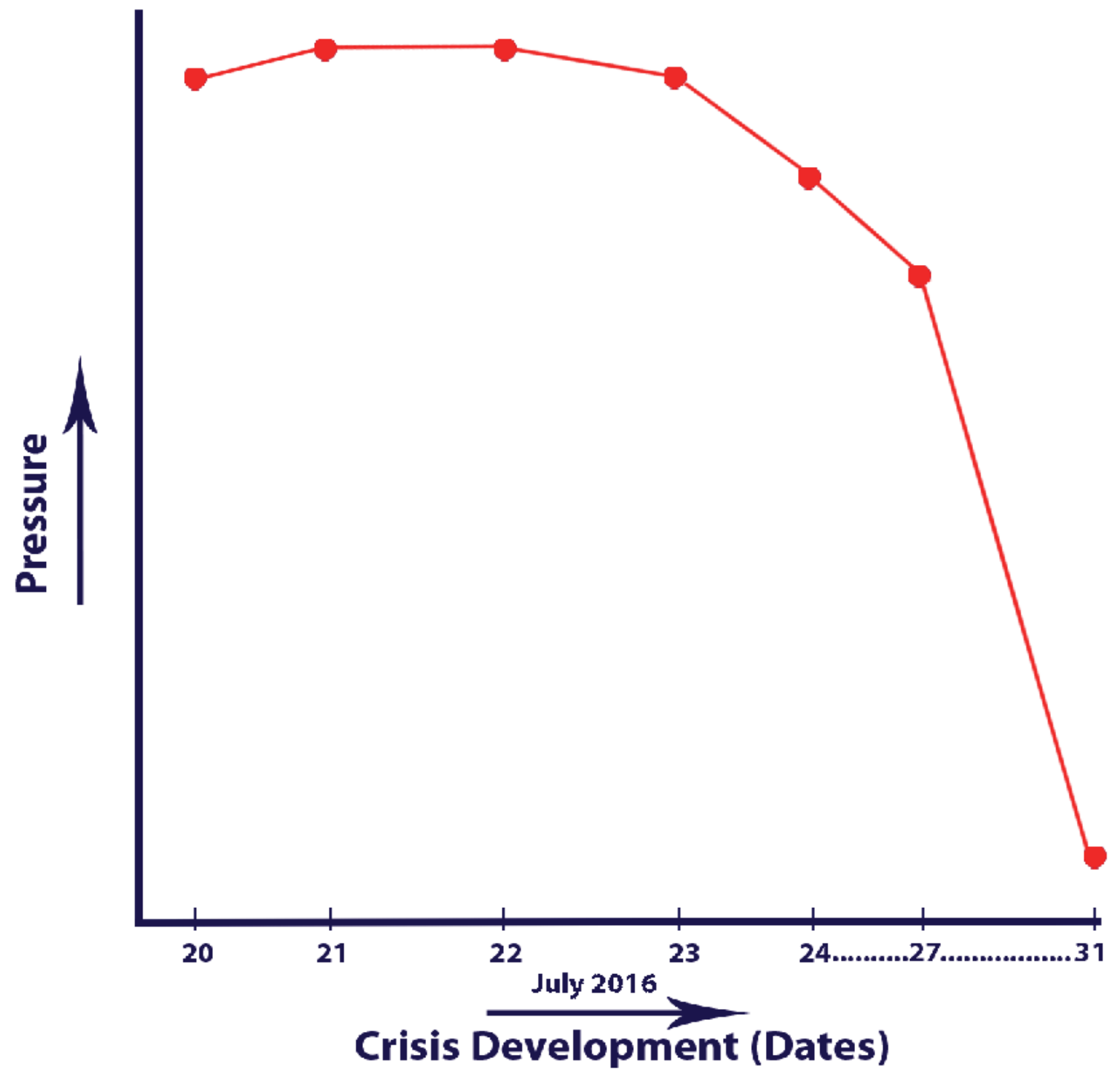

\section{Origin}

July 20: Crises birth- Partial meltdown on operational activity and computer based error (connectivity issue).

\subsection{Mediation/Amplification}

July 21: System blackout nationwide cancellation of 1000's of flights and increasing. Influx of social media posts and media attention full-fledged.

July 22-23: The crisis continues with travellers stranded at the airport, frustrated and angry. Company compensating and offering alternative options for flights.

\subsection{Resolution}

July 24-31: Crisis level subsiding to a normal level by July 31st, Southwest back on track evaluating its performance.

5.3 Impact of Crisis on Stakeholders

The crisis impacted on some identifiable stakeholders within the aviation industry. The passengers who were the victims, their families, employees (especially CEO, technical and communication teams), media, Regulatory Authorities in the United States and future southwest travelers. 
Table 4. Impact of crisis on stakeholders and their reactions to the crisis

\begin{tabular}{|c|c|}
\hline Affected victims & How they reacted to the crisis \\
\hline Passengers/travelers & $\begin{array}{l}\text { These were the mostly affected stakeholders } \\
\text { in the crisis. Booked for business meetings, } \\
\text { job interviews, family and friends visits and } \\
\text { holidays these passengers were frustrated } \\
\text { and disappointed at the power outage } \\
\text { They took to social media expressing their } \\
\text { displeasure and dissatisfaction of southwest } \\
\text { services. } \\
\text { Emotions were high for some who were } \\
\text { missing very important meetings and } \\
\text { interviews. } \\
\text { Some passengers out of rage, displeasure and } \\
\text { disappointment demanded for a refund. }\end{array}$ \\
\hline Families of passengers & $\begin{array}{l}\text { A feeling of anxiety swept away family members who } \\
\text { could not keep in touch with their loved ones. Some } \\
\text { also took to social media to express their } \\
\text { disappointments. }\end{array}$ \\
\hline $\begin{array}{l}\text { CEO, technical and communications teams } \\
\text { (Company's response) }\end{array}$ & $\begin{array}{l}\text { These employees were directly impacted by } \\
\text { the crisis. They were the face of the company } \\
\text { They were apt and quick at responding to } \\
\text { most social media questions and giving } \\
\text { updates } \\
\text { They were smart at acknowledging and } \\
\text { owning the crisis and offering apology to } \\
\text { stakeholders affected } \\
\text { They gave assurance, encouragement and } \\
\text { affordable booking accommodation for } \\
\text { customers, as well as compensation and } \\
\text { refund. }\end{array}$ \\
\hline Media & $\begin{array}{l}\text { The media were very keen at finding out the possible } \\
\text { cause of the outage. They provided from across } \\
\text { airports in the United States news about the } \\
\text { happenings, updates and liaising with Southwest } \\
\text { airline to inform the public. Though the crisis made } \\
\text { headlines in majority of media in the States, the news } \\
\text { did not contain false information and negative stories } \\
\text { that could tarnish the company's reputation. }\end{array}$ \\
\hline Regulatory Authorities & $\begin{array}{l}\text { As a regulatory body responsible for power } \\
\text { supply, The Federal Energy Regulatory } \\
\text { Commission (FERC) and the North } \\
\text { American Electric Reliability Corporation } \\
\text { expressed worry over the power outage that } \\
\text { led the cancellation of over } 2,000 \text { flights in } \\
\text { the American airline history. } \\
\text { These regulatory bodies in a way of } \\
\text { protecting customers from such occurrence } \\
\text { issued a statement and copied NBC News } \\
\text { cautioning all airlines and launching } \\
\text { investigation into the crisis. } \\
\text { The statement published by NBC stated that } \\
\text { Southwest airline could be fined if there was } \\
\text { any violation. }\end{array}$ \\
\hline
\end{tabular}

\subsection{Communication Strategy by Southwest airline}

On Wednesday July 20, 2016, Southwest Airline experienced a massive technical failure leading to the cancellation of over 2,000 flights and delaying 250,000 customers at the various airports across United States (CBS News, 2016). The four-day uproar within the airline company saw huge sums of dollars going down the drain and the credibility and reputation falling into a ditch. The airline was besieged by the "red hot anger of some 250,000 irate passengers" (Convince and Convert, 2016). Known for its good customer service and less expensive fares, the Texas airline remained 
calm, resolute and committed to maintaining its integrity, credibility and reputation. These were the communication strategies put in place to minimize the level of damage the crisis caused.

\subsection{Recognizing Crisis, Owning and Offering Apology}

This is one of the key strategies Southwest airline used to humanize the crisis and empathized with affected travelers. It is quite a challenge for most companies to publicly offer an apology in times of crisis because it is believed it opens the company to legal liabilities (Aula 2010). On the other hand, companies that come out to own crisis and apologize are perceived by the public as socially responsible. And that is exactly what Southwest airline did. This is evident in some tweets by the airline (see image 3 )

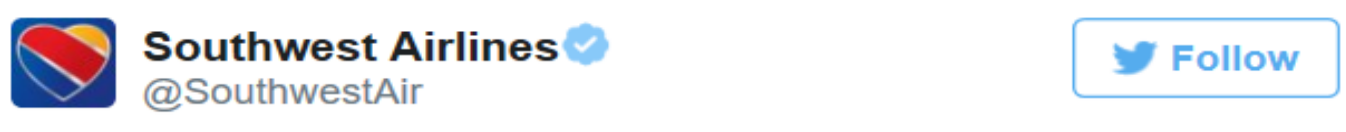

\section{@youloveit32 We're so sorry to hear about the cancellation and we cannot thank you enough for your patience with our services today. ${ }^{\wedge} \mathrm{AC}$}

9:29 AM - 22 Jul 2016

Image 3. Southwest's twitter apology (Southwest Twitter, 2016)

\subsection{Live Facebook Videos and Updates}

One of the innovative strategies adopted by Southwest airline was live Facebook videos and updates. Pulled together by the chief technical officer, Thomas Brooks, in the live facebook video was the chief operating officer, Linda Rutherford who reaffirmed the company's stance on how sorry they were and assured travelers of the efforts put in place to restore the power outage. The video showed Linda Rutherford explain the company's current position and how they are resolving the issue, thus adding huge credibility to the video post. The video had a far reach of about 195,000 views; 1,300 likes; 1,200 comments and 545 shares (Southwest Facebook, 2016)

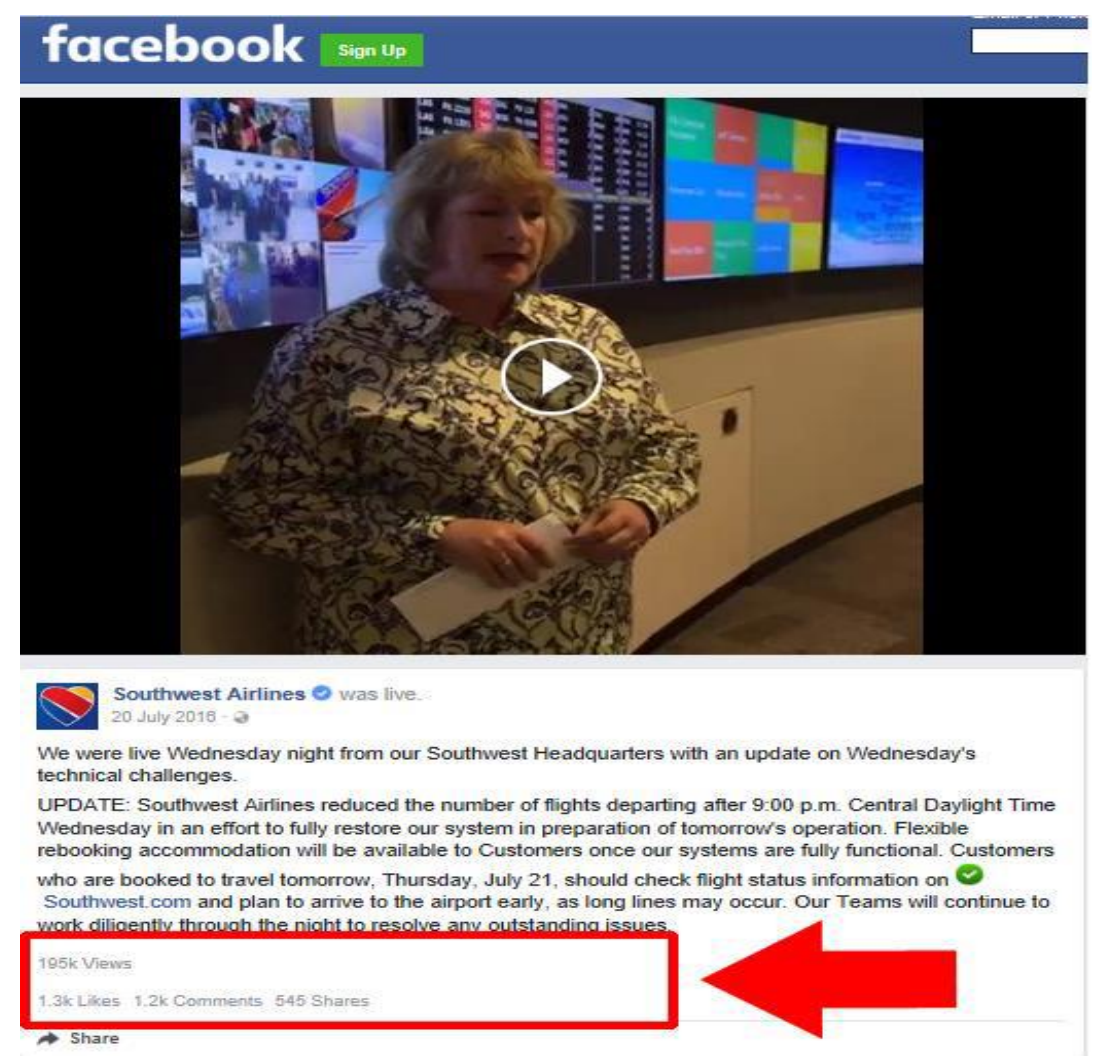

Image 4. Facebook live video statistics (Southwest Facebook, 2016 


\subsection{Quick Responses}

Research shows that $40 \%$ of users on social media expect a quick answer for their posted complain from any brand or company within in the 60mins timeframe (Aula, 2010). According to Doorley and Garcia (2011) an effective crises solution is responding to all the effected parties (stakeholders) within the $45 \mathrm{mins}$ golden timeframe beyond which could turn fatal for businesses.

Southwest airline communications team was apt and about with responses on all social media pages. Though they were not able to respond to every complaint posted by customers, they were able to address many complaints with swiftness. The company realised that every social media channel they had was a customer service channel. As such, some complaints on all social platform including LinkedIn were addressed and assurance given. Some customers expressed satisfaction over the swift responses and assurance.

\subsection{Southwest Website Linked to Social Networks}

The company foresaw that in times of crisis like this, the company's website could not be the only home for the crisis to be resolved. Another innovative strategy the company adopted was the multi-channel amalgamation. All social networks of the company except instagram were linked to the company's website. This means all information and updates on the website automatically appeared on the social networks. This strategy ensured information reached the fragmented travelers who belonged to different social networks and accessed their information from various sources never missed out. Forinstance the company's update and apology message on its website was also shared directly on Facebook and LinkedIn.

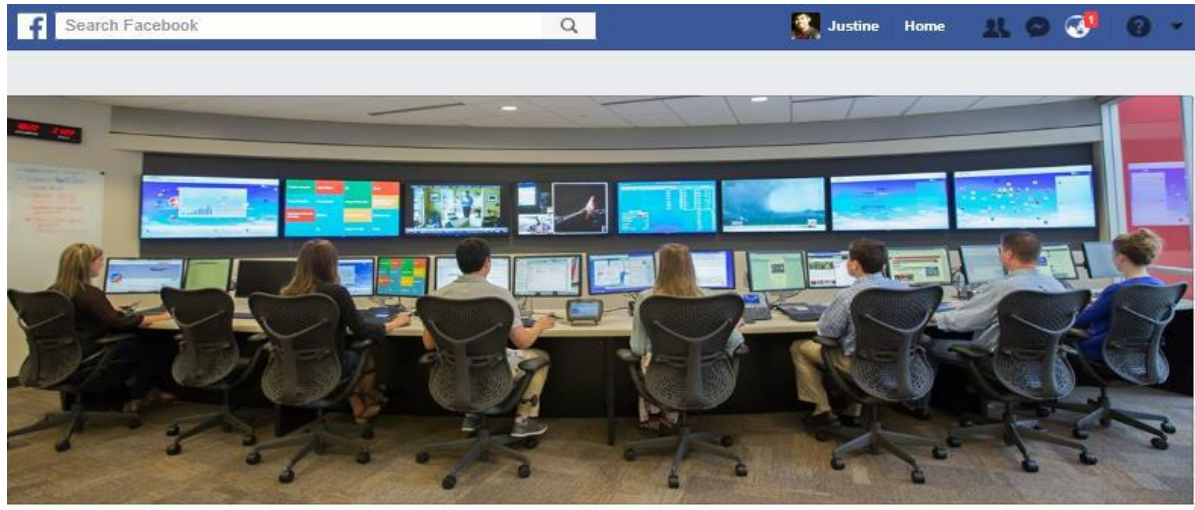

\section{An Update and an Apology on Systemwide Outages}

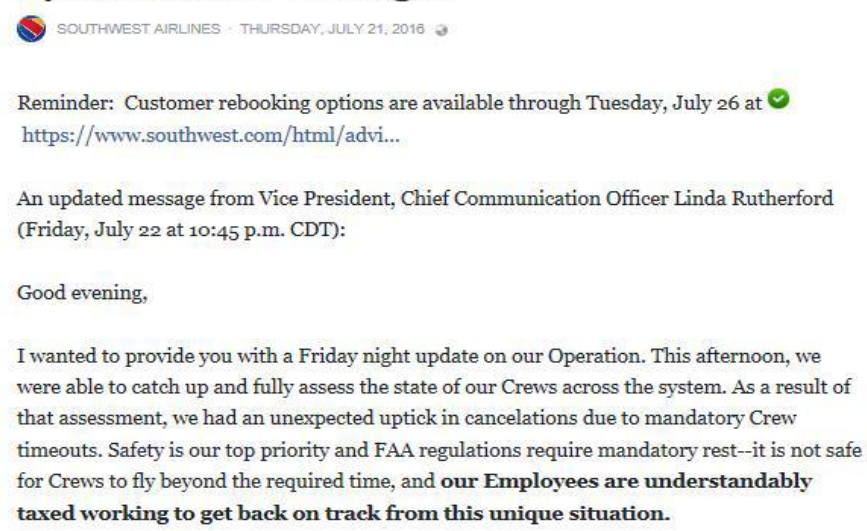

Image 5. Southwest quickly responding to twitter customer feeds (Southwest Twitter)

\section{Conclusion and Recommendation}

Southwest adopted a strategy that minimalize the level of impact of the crisis i.e. they first identified the key problem of the fallout, acknowledged it and quickly responded back to all its stakeholders and their complaints within an appropriate time frame.

Although it was an accidental crisis, management tackled the situation strategically. Southwest's decision to respond to the customer's posts natively on their personal preferred channel worked well in the company's favour. The company is seen to 
have embraced the core principles of communication before the social media storm hit them hard i.e., transparency, honesty, genuineness, swiftness, progressiveness and the use of multiple social channels for updating customers.

These communication strategies and tactics were satisfactory enough to help the company regain its reputation and credibility through positive posts from travelers. Though travelers were disappointed and expressed their displeasure on social networks, some were satisfied with the communication and periodic updates and commended Southwest Airline communication and technical teams for working hard behind the scenes to get them to their destinations.

It is recommended that organisations adopt multiple use of social channels to meet customers' needs and preferences. And the readiness of organisations to respond swiftly to social media messages will save it from social crisis, especially in the case of negative social comments or posts.

\section{References}

Aula, P. (2010). Social media, reputation risk and ambient publicity management, Strategy \& Leadership, 38(6), 43-49, Business Source Complete, Deakin Library Database. https://doi.org/10.1108/10878571011088069

Carter, D., Rogers D., \& Simkins, B. (2014). Does Fuel Hedging Make Economic Sense? The Case of the US. Airline Industry, Oklahoma State University.

CBS News (2016). Southwest Airlines computer outage grounds fleet nations, CBS News. Retrieved May 26, 2018. www.cbsnews.com.

Charley, D. M. (2016). Twitter post, Southwest. Retrieved May 25, 2018.

Chong, D., \& Druckman, J. (2007). Framing Theory, Department of Political Science, Northwestern university.

Conor, S. (2016). 2,300 flights cancelled, Southwest Airline recovers from technical outage, Dallas News, 2016. Retrieved May 25, 2018. www.dallasnews.com.

Coombs, W. T., \& Holladay, S. J. (2010). The handbook of crisis communication, Wiley-Blackwell, Chichester, UK. https://doi.org/10.1002/9781444314885

Coombs, W. T. (2012). Ongoing crisis communication, $3^{\text {rd }}$ edn, Sage, Thousand Oaks.

Coombs, W. T. (2007). Protecting Organisations Reputations during a Crisis: The Development and Application of Situational Crisis Communication Theory, Corporate Reputation Review, 10(3), Google Scholars. Retrieved May 26, 2018.

Doorley, J., \& Garcia, H. F. (2015). Reputation management, The Key to Successful Public Relations and Corporate Communication, 3rd edn, Routledge, New York. https://doi.org/10.4324/9781315879987

Regester, M., \& Larkin, J. (2008). Risk issues and crisis management in public relations: a casebook of best practice, 4th edn, Kogan Page, London.

Southwest Facebook, (2016). Live Facebook video update, Facebook. Retrieved May 26, 2018. https://www.bing.com/news/search?q=Southwest+Airline+Facebook+Live+Video+On+Apology\&qpvt=southwest +airline+facebook+live+video+on+apology\&FORM=EWRE

Southwest stock report, (2014). Stock and investment analysis, University of Oregon investment group, retrieved 2 June 2017, < https://www.uoinvestmentgroup.org/wp-content/uploads/2015/04/Southwest-Airlines-Report-2014.pdf>.

Southwest Twitter posts, (2016). Twitter. Retrieved May 25, 2018. https://www.bing.com/news/search?q=Southwest+Airline+apology+twitter+posts+on+2016+power+outage \&qs=n $\&$ form=QBNT\&sp=-1\&pq=southwest+airline+apology+twitter+posts+on+2016+power+outage \&sc $=0-60 \&$ sk $=\& c$ vid=0A900A681EA947BAA2320F54542ACF0E

Southwest update \& apology, (2016). An update and an apology on system wide outage, Facebook, retrieved 2 June 2017, https://www.facebook.com/notes/southwest-airlines/an-update-and-an-apology-on-systemwide-outages/101544941 96178949/>

Southwest, n.d., About Southwest, Southwest Airlines, retrieved 1 June 2017, <www.southwest.com>

\section{Copyrights}

Copyright for this article is retained by the author(s), with first publication rights granted to the journal.

This is an open-access article distributed under the terms and conditions of the Creative Commons Attribution license which permits unrestricted use, distribution, and reproduction in any medium, provided the original work is properly cited. 